\title{
Toxoplasmosis seroprevalence in urban rodents: a survey in Niamey, Niger
}

\author{
Aurélien Mercier ${ }^{1 /}{ }^{+}$, Madougou Garba ${ }^{2,3,4}$, Henri Bonnabau ${ }^{5}$, Mamadou Kane ${ }^{6}$, \\ Jean-Pierre Rossi', Marie-Laure Dardé1,8, Gauthier Dobigny ${ }^{2,7}$
}

'Laboratoire de Parasitologie-Mycologie, Faculté de Médecine, Université de Limoges, Unité Mixte de Recherche 1094, Neuroépidémiologie Tropicale, Institut National de la Santé et de la Recherche Médicale, Limoges, France

2Département Formation Recherche, Centre Régional AGRHYMET, Rive Droite, Niamey, Niger ${ }^{3}$ Faculté des Sciences, Université Abdou Moumouni, Niamey, Niger ${ }^{4}$ Direction Générale de la Protection des Végétaux, Niamey, Niger

${ }^{5}$ Unité Fonctionnelle de Recherche Clinique et de Biostatistique, Service de l'Information Médicale et de l'Évaluation, Centre Hospitalier Universitaire de Limoges, Limoges, France ${ }^{6}$ Institut de Recherche pour le Développement, Centre de Biologie pour la Gestion des Populations (Unité Mixte de Recherche, Institut de Recherche pour le Développement/Institut National de Recherche Agronomique/Centre de Coopération Internationale en Recherche Agronomique pour le Développement/MontpellierSupAgro), Campus de Bel-Air, Dakar, Sénégal ${ }^{7}$ Institut National de Recherche Agronomique, Unité Mixte de Recherche 1062, Centre de Biologie pour la Gestion des Populations (Institut National de Recherche Agronomique, Institut de Recherche pour le Développement, Centre de Coopération Internationale en Recherche Agronomique pour le Développement, Montpellier SupAgro), Centre de Biologie pour la Gestion des Populations, Campus International de Baillarguet Montferrier-sur-Lez, France ${ }^{8}$ Centre Hospitalier-Universitaire Dupuytren, Centre National de Référence Toxoplasmose/Toxoplasma Biological Resource Center, Limoges, France

A serological survey of Toxoplasma gondii was conducted on 766 domestic and peridomestic rodents from 46 trapping sites throughout the city of Niamey, Niger. A low seroprevalence was found over the whole town with only $1.96 \%$ of the rodents found seropositive. However, differences between species were important, ranging from less than $2 \%$ in truly commensal Mastomys natalensis, Rattus rattus and Mus musculus, while garden-associated Arvicanthis niloticus displayed $9.1 \%$ of seropositive individuals. This is in line with previous studies on tropical rodents - that we reviewed here - which altogether show that Toxoplasma seroprevalence in rodent is highly variable, depending on many factors such as locality and/or species. Moreover, although we were not able to decipher statistically between habitat or species effect, such a contrast between Nile grass rats and the other rodent species points towards a potentially important role of environmental toxoplasmic infection. This would deserve to be further scrutinised since intra-city irrigated cultures are extending in Niamey, thus potentially increasing Toxoplasma circulation in this yet semi-arid region. As far as we are aware of, our study is one of the rare surveys of its kind performed in Sub-Saharan Africa and the first one ever conducted in the Sahel.

Key words: Toxoplasma gondii - epidemiology - zoonotic disease - Africa - Sahel

Sahel is a sub-arid region that undergoes rapid climatic changes (Lebel \& Ali 2009) with dramatic consequences on food production and availability. Such a critical situation leads to a massive rural exodus and extensive urbanisation. Niamey, the main town of Niger, is no exception. Since the 1960s, the population of this rather young city has been undergoing an explosive increase due to a very important demographic growth (Sidikou 2011). The number of inhabitants has increased from $\sim 3,000$ in the $1920 \mathrm{~s},>30,000$ in the late $1950 \mathrm{~s}$ to 707,000 in 2001 and reached more than 1.2 million in 2010 (Sidikou 2011, Adamou 2012). As often in such cases, this was accompanied by many informal settlements and insufficient tracking of necessary sanitary services.

doi: 10.1590/0074-0276108042013002

Financial support: CBGP (UMR IRD/INRA/Cirad-Montpellier

SupAgro)

+ Corresponding author: aurelien.mercier@pasteur.fr

Received 21 November 2012

Accepted 12 April 2013
Along with other problems, public health is a primordial concern with low clinical capacities and poor accessibility to medical care. In addition, robust epidemiological data for Niger remains scarce for many major diseases such as malaria and human immunodeficiency virus (HIV). From there, other pathologies are even more poorly documented, when not undetected, due to weak screening programs and/or diagnostic facilities. Among them, the worldwide distributed toxoplasmosis is induced by the intracellular protozoan Toxoplasma gondii whose infection may be asymptomatic to lethal, with primo-infection being particularly dangerous during pregnancy due to subsequent abortion or severe clinical consequences on foetus and neonate. Moreover, toxoplasmosis appears as an opportunistic disease in immuno-depressed patients such as HIV-positive ones (Robert-Gangneux \& Dardé 2012).

In sub-Saharan Africa, human prevalence [reviewed in Mercier (2010)] ranges from 3.9\% in Niger (Delacroix \& Laporte 1989) to $83.5 \%$ in Madagascar (Lelong et al. 1995). In Niger, toxoplasmosis has only been the focus of five studies and seroprevalence values were found to be quite variable, ranging from $3.9-50.5 \%$, with an aver- 
age of $12.8 \%$ for the whole country (Table I). A survey conducted on 218 pregnant women in Niamey showed a slightly higher value (i.e. $15.1 \%$ ) and the most recent survey for the city indicated a global seroprevalence of $18.1 \%$ (Table I). On this basis, previous authors have considered toxoplasmosis not to be of primary importance for public health in Niger. Medical monitoring of pregnancy is still poor - when not null - for many women, thus making robust statistics difficult to obtain. Perinatal outcomes, including spontaneous abortion and stillbirth children, seem not to be rare in Niger: the National Service for Sanitary Information (SNIS) evaluate stillborn children to reach $8 \%$ (SNIS 2010). In 2010, 37\% of patient admissions in the reference maternity hospital in Niamey concerned "abortions" (SNIS 2010). However, such statistics need to be handled with great care since many - if not most - of these cases may be due to complications following illegal abortions (voluntary termination is prohibited in Niger). Such a large proportion of perinatal complications may cast doubt on our perception of the real incidence of the disease in the country. We are aware of no systematic and large-scale monitoring of the disease that would allow one to robustly address the respective role of toxoplasmosis.

Transmission to human and warm-blooded animals occurs via three primary ways, congenitally, by ingestion of food and water contaminated with oocysts shed into the environment in faeces of felids (domestic cat or wild felids) or by the ingestion of undercooked meat containing tissue cysts. Although felids are the only known definitive host, $T$. gondii may infect all homoeotherm animals (i.e. birds and mammals), which then act as intermediate hosts (Tenter et al. 2000). Among them, rodents are found in most types of terrestrial biotopes, where they constitute important prey for wild as well as domestic felids. Moreover, they are usually among the last wild mammals to persist in highly human-modified environments, like large towns. For these reasons, rodents most probably play a pivotal role in the maintenance and circulation of T. gondii in urban habitats (Dubey \& Frenkel 1998, Murphy et al. 2008). A study conducted in the city of Lyon, France, suggested that low Toxoplasma prevalence in stray cats may be in part associated with low rodent densities (Afonso et al. 2006). Surprisingly, however, epidemiological surveys of $T$. gondii in rodents are scarce, especially those dealing with tropical regions (Supplementary data). Seroprevalences were found to be highly variable depending on the species and/or the region. In Sub-Saharan Africa, where only two studies were conducted (Supplementary data), 100\% of seropositive Thryonomys swinderianus individuals $(\mathrm{n}=104)$ were found in South Western Nigeria, while only $2.7 \%$ and $2.3 \%$ of positive wild and commensal rodents were detected in Gabon ( $\mathrm{n}=37$ and 43, respectively) (Supplementary data). To our knowledge, no such survey has ever been conducted in Sahelian countries.

Recently, human-mediated transport of invasive rodents has been shown to be responsible for the import of allochtonous human pathogens (Dobigny et al. 2011). This motivated a long-term program that aimed to investigate rodents and rodent-borne human pathogens in the city of Niamey. As part of this wider project, we here provide serological results for Toxoplasma that were obtained from 766 rodents. Seroprevalence data are then discussed in regard to native and invasive rodent host species distribution, as well as urban environments in terms of transmission risk to human populations.

\section{MATERIALS AND METHODS}

Sampling and species-specific identifications of rodents - From 2009-2011, a multi-approach monitoring of urban rodents was performed in order to address several issues including epidemiological ones. To do so, more than 14,560 night-traps were performed using both Sherman and locally made wire-mesh traps in various sites and habitats (houses, gardens, markets as well as industrial-like structures) dispersed throughout the city. As part of this project, we here focus on a serologic survey

TABLE I

Recapitulation of studies conducted in Niger and dealing with Toxoplasma seroprevalence in human

\begin{tabular}{|c|c|c|c|c|}
\hline \multirow[b]{2}{*}{ References } & \multirow[b]{2}{*}{ Geographic level } & \multirow[b]{2}{*}{ Target population } & \multicolumn{2}{|c|}{ Raw seroprevalence } \\
\hline & & & NIT & $(\%)$ \\
\hline Dumas et al. (1985) & NA & $\begin{array}{l}\text { Infants } \\
\text { Their mother }\end{array}$ & $\begin{array}{l}14 \\
14\end{array}$ & $\begin{array}{l}42.9 \\
58.1\end{array}$ \\
\hline Develoux et al. (1988) & Niamey and surroundings & $\begin{array}{l}\text { General population } \\
\text { Urban population } \\
\text { Rural population }\end{array}$ & $\begin{array}{l}400 \\
199 \\
201\end{array}$ & $\begin{array}{l}18.2 \\
11.5 \\
24.8\end{array}$ \\
\hline Develoux et al. (1989) & Niamey & Pregnant women & 218 & 15.1 \\
\hline Delacroix \& Laporte (1989) & Akokan (Arlit) & Women of reproductive age & 229 & 3.9 \\
\hline Dumas et al. (1991) & Arlit & $\begin{array}{l}\text { Pregnant women } \\
\text { Infants }\end{array}$ & $\begin{array}{c}242 \\
77\end{array}$ & $\begin{array}{l}5.4 \\
2.6\end{array}$ \\
\hline Julvez et al. (1996) & Niamey and surroundings & General population & 371 & 18 \\
\hline
\end{tabular}

NA: not available; NIT: number of individuals tested for toxoplasmosis. 
of rodent-borne Toxoplasma, which concerns a sub-total of 46 trapping sites (Figure, Supplementary data).

A trapping site corresponds either to one or several contiguous gardens (J-CGA, J-CYA, J-DAR, J-KIR1, JKIR2, J-LMO and J-NOG) (Supplementary data), fallow lands (CRA-1, CRA-2 and CRA-3), administrative buildings (PGP), markets (PEM and GRM-M), industrial food stores (COA, RTO), slaughter house (ABA) or habitation areas (all others) (Supplementary data). All sites lie within the city of Niamey (Figure) (part of a Spot Image, scene reference 50613230812101015132 T, CNES $2008^{\circ}$, obtained under licence through the ISIS program, file 553) where they were precisely geo-referenced (e.g., each individual habitation where rodents were captured) in order to be mapped onto a satellite image. However, for the purpose Supplementary data as well as Figure, they were aggregated for a clearer visualisation at the whole town scale.

Rodents were live-trapped and brought to the lab where they were usually euthanised within one-eight days, except for 45 of them which were autopsied within eight-23 days (data not shown). All procedures were carried out in agreement to current ethical guidelines for animal care. The age was scored according to weight [following Granjon \& Duplantier (2009)] together with sex activity (external testicles plus active seminal vesicles in males; developed mammaes and uterus, presence of embryos and/or embryo scars in females). Intracardiac blood was sampled immediately after death and deposited onto LDA22 Guthrie cards (LDA Laboratory, Saint Brieux, France). The blotting papers were dried and stored in a plastic bag at room temperature (RT).

In order to avoid misidentification of rodents due to the possible co-existence of sibling species in West African rodents [reviewed in Granjon \& Duplantier (2009)], special attention was paid to species-specific diagnosis.
To do so, specimens were all unambiguously identified (Supplementary data) using morphology-based criteria (genus Cricetomys), karyotyping (Mastomys, Taterillus and Arvicanthis), polymerase chain reaction-restriction fragment length polymorfism (PCR-RFLP) (Mastomys) and/or genotyping (Mastomys and Rattus). All details are provided in Garba (2012).

Serological survey of T. gondii - Dried blood spot samples collected on Guthrie card were tested for the detection of $T$. gondii antibodies. Seven hundred and sixty six rodents were screened at 1:16, 1:32, 1:320 and 1:640 dilutions using a modified agglutination test (MAT) technique (Desmonts \& Remington 1980) adapted for blood sample from Guthrie cards, with a cut-off titre at 1:16. Two $5 \mathrm{~mm}$ diameter dried blood spot were punched out of each blotting paper circle and placed into the well of a flat bottomed microtitre plate. The blood was eluted out in $80 \mu \mathrm{L}$ of phosphate buffered saline, $\mathrm{pH} 7.2$ (bioMérieux). Plates were covered and left to elute overnight at RT and at $300 \mathrm{rpm}$ agitation. Ten microlitres of each eluted sample was used in MAT technique. For serological control, fresh blood from seronegative (not infected by $T$. gondii) and seropositive (experimentally infected with a control of the presence of cysts into the brain) Swiss mice (Mus musculus, Charles River France, L'Arbresle, France) for T. gondii antibodies were spotted onto a $5 \mathrm{~mm}$ diameter circle on Guthrie card and allowed to dry at RT for $24 \mathrm{~h}$, before storage at RT in sealed bags. Antibody titres were determined by the last dilution where agglutination pattern could be read in comparison with the negative and positive controls.

Statistical analysis - Descriptive analyses of the serological data were based on frequencies, percentage for qualitative variables and means, standard deviations for quantitative variables. Relationships between rodent se-
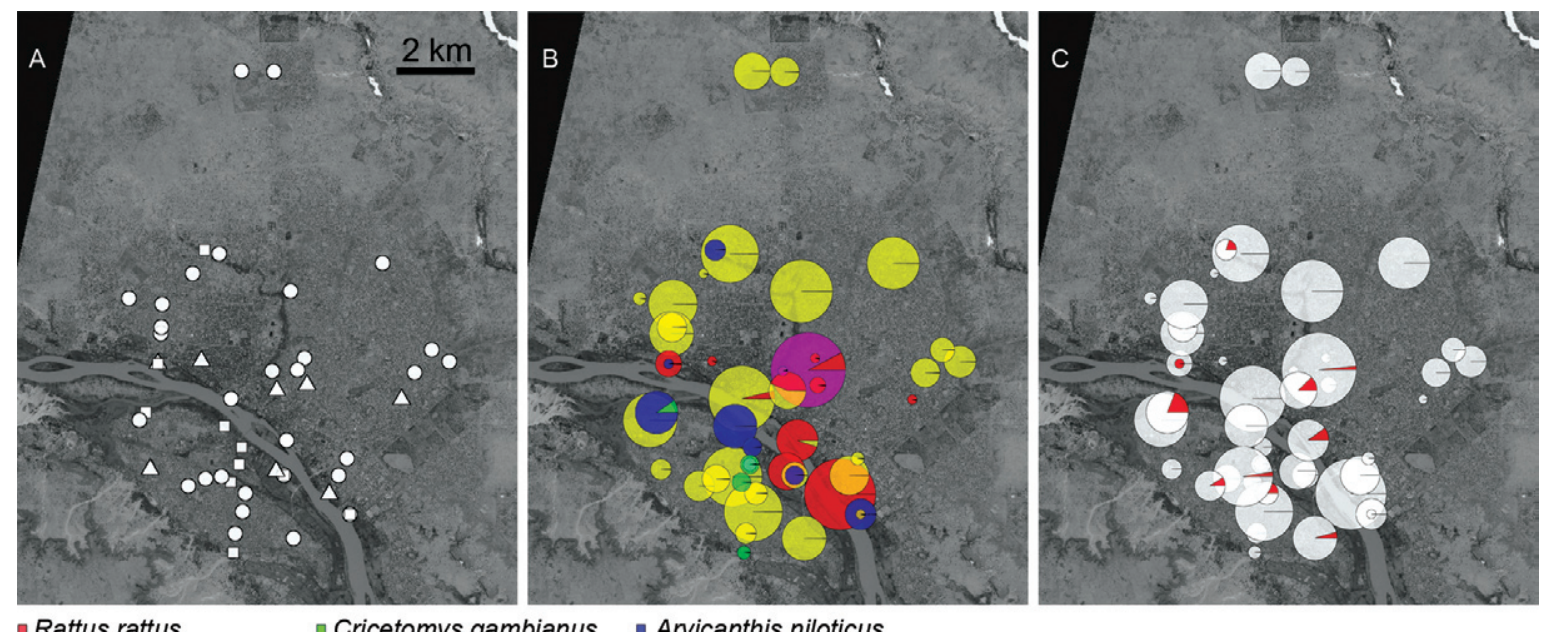

Mastomys natalensis $\square$ Taterillus gracilis

- Mus musculus

Distribution map of the different trapping sites within Niamey with squares, circles and triangles corresponding to (i) fallow lands and gardens, (ii) habitations and (iii) other site types (industrial-like spots, public buildings, markets and transport stations), respectively (A). Respective parts of rodent species trapped at each trapping site. Circle sizes are proportional to the number of rodent captures (B). Respective parts of seropositive and seronegative rodents detected at each trapping sites. As for B, circle sizes are proportional to the number of rodents that were investigated for Toxoplasma serology. White and red colours indicate seronegative and seropositive rodents, respectively (C). 
roprevalence and factors such as sex, species and habitats were investigated through chi-squared test or Fisher's exact test, depending on the expected sample size. For each significant factor, a Cochran-Mantel-Haenszel Chi-Squared test was conducted in order to obtain a pvalue adjusted for the other factors. All statistics were performed using the software R v2.10.1 (R Development Core Team 2009).

\section{RESULTS}

From the 46 trapping sites sampled for the present study, 766 rodents could be surveyed for Toxoplasma serology: 123 were black rats (Rattus rattus), 61 were house mice (M. musculus), 66 were Nile grass rats (Arvicanthis niloticus), 12 were giant Gambian rats (Cricetomys gambianus), two were slender gerbils (Taterillus gracilis) and 502 belonged to the genus Mastomys (Supplementary data). Among the latter, 287 were investigated using PCRRFLP designed by Lecompte et al. (2005) and all but two individuals displayed characteristic Mastomys natalensis profiles as defined by Lecompte et al. (2005). Two animals possessed atypical profiles (not shown) and so were fully sequenced for their cytochrome $b$ mitochondrial gene. These DNA sequences allowed to barcode them and to unambiguously identify them as $M$. natalensis (Dobigny et al. 2008, 2011). In addition, all karyotyped Mastomys (20 of which had not been molecularly characterised) showed a $2 \mathrm{~N}=32$ karyotype typical of $M$. natalensis (Dobigny et al. 2008). These 307 unambiguously identified $M$. natalensis represent $61.2 \%$ of the whole Mastomys sample available in the present study. Moreover, they originated from all 30 trapping sites were Mastomys individuals were trapped (Supplementary data). No representative of other Mastomys species has ever been found within the city of Niamey even in the framework of wider investigations (n $>650$ Mastomys) (K Hima, unpublished observations). We can therefore conclude that all Mastomys that were trapped in the present survey belong to one single species, namely M. natalensis.
Seropositive individuals represent $1.96 \%$ of the total rodent samples (15 out of 766) (Tables II, III, Supplementary data). MAT titres were 1:16 in six, 1:32 in four and 1:640 in five rodents (Table III). The 15 seropositive animals were found in nine different trapping sites (Figure, Supplementary data) which include CGA, GAW, GNA, GRM, KAR, KAR-1, PEM, J-CYA and J-LMO (Table II, Supplementary data). They belong to four different species: the native $M$. natalensis $(\mathrm{n}=6$ out of 502 , $1.2 \%)$ and A. niloticus ( $\mathrm{n}=6$ out of $66,9.1 \%$ ) and the invasive $R$. rattus ( $\mathrm{n}=2$ out of $123,1.6 \%)$ and $M$. musculus $(\mathrm{n}=1$ out of $61,1.6 \%)$ (Supplementary data). No seropositive individuals were found in C. gambianus and T. gracilis; however, these two species were represented by very low sample sizes ( $\mathrm{n}=12$ and 2 , respectively) (Supplementary data).

Seropositive individuals included both juvenile and adult animals as well as males and females (Table III). In most instances, they corresponded to one single seropositive specimen found within five- 65 specimens from one particular trapping site; only in two exceptions (CGA and J-LMO) did we find several seropositive animals within the same trapping site (Table III, Supplementary data). Finally, in three instances, seropositive individuals were part of multiple captures (i.e. several rodents trapped together inside the same trap): two juvenile $M$. natalensis that were both seropositive, one adult $R$. rattus female trapped with a seronegative juvenile and two juvenile $A$. niloticus caught with a seronegative female (Table III).

There was no significant relationship between seropositivity and sex of the rodents $(\mathrm{p}=0.3)$. On the contrary, both species and habitat significantly affected seropositivity $(p=0.0017$ and $p=0.0001$, respectively) with no interaction $(p=0.77)$. Accordingly, the relationships between species and seropositivity (adjusted for habitat) and habitat and seropositivity (adjusted for species) were both significant by the Mantel Haensel test ( $p$ $=0.0001$ and $\mathrm{p}=0.0001$, respectively).

TABLE II

Rodent captures as well as number of seropositive individuals per species and habitat types

\begin{tabular}{|c|c|c|c|c|c|c|}
\hline \multirow[b]{2}{*}{ Species } & \multirow{2}{*}{$\begin{array}{l}\text { Total } \\
\text { (n) }\end{array}$} & \multicolumn{4}{|c|}{$\begin{array}{c}\text { Rodents (seropositive) } \\
\text { n (n) }\end{array}$} & \multirow{2}{*}{$\begin{array}{c}\text { Seropositive } \\
\text { n (\%) }\end{array}$} \\
\hline & & Industrial $^{a}$ & Gardens & Houses & Markets & \\
\hline Arvicanthis niloticus & 66 & $0(0)$ & $66(6)$ & $0(0)$ & $0(0)$ & $6(9.1)$ \\
\hline Rattus rattus & $122^{b}$ & $82(0)$ & $3(0)$ & $27(2)$ & $10(0)$ & $2(1.6)$ \\
\hline Mus musculus & 61 & $0(0)$ & $0(0)$ & $61(1)$ & $0(0)$ & $1(1.6)$ \\
\hline Mastomys natalensis & 502 & $7(0)$ & $9(0)$ & 477 (4) & $9(2)$ & $6(1.2)$ \\
\hline Taterillus gracilis & 2 & $0(0)$ & $2(0)$ & $0(0)$ & $0(0)$ & $0(0)$ \\
\hline Cricetomys gambianus & 12 & $0(0)$ & $12(0)$ & $0(0)$ & $0(0)$ & $0(0)$ \\
\hline Total & 765 & $89(0)$ & $92(6)$ & $564(7)$ & $19(2)$ & $15(1.96)$ \\
\hline
\end{tabular}

$a$ : firms, slaughter house, industrial storage houses and public buildings (Supplementary data); $b$ : one seronegative rat has an ambiguous geographic origin (Supplementary data) and could not be included. 


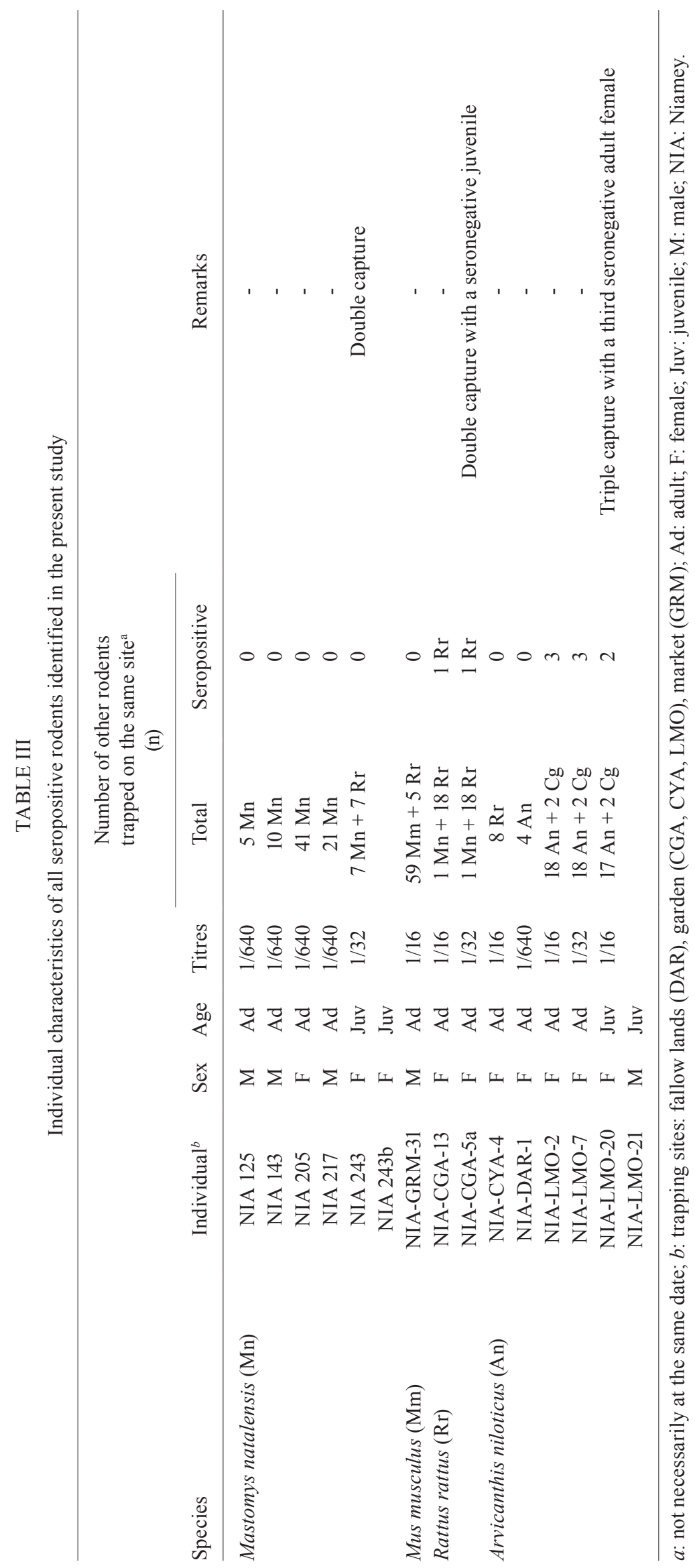




\section{DISCUSSION}

The present study, the first one of its kind in Sahel, relies on an important collection of rodent blood samples $(n=766)$. Represented rodent species are typical Sahelian species that were all already known in the area (Dobigny et al. 2002), with both native (A. niloticus, C. gambianus, $M$. natalensis and $T$. gracilis) and invasive $(M$. musculus and R. rattus) species (Granjon \& Duplantier 2009). Although differentiating between rural and urban environments in Niamey may sometimes be tricky since the two types of habitats are often continuous when not fully intermingled (houses closely surrounding or lying within gardens and rice fields, gardens within familial concessions etc), rodent species distribution in regards to biotopes was quite clear: A. niloticus, C. gambianus and $T$. gracilis inhabit gardens and fallow lands, while $M$. natalensis, $R$. rattus and $M$. musculus are typical commensal animals.

Global T. gondii seroprevalence in rodents from Niamey was low $(<2 \%)$, a result that closely matches those found in Gabon during one of the rare other rodent-focused study performed to date in Sub-Saharan Africa (Mercier 2010) (2.3\% and 2.7\% of 43 commensal and 37 wild rodents, respectively). This parallels previous studies where positive urban rodents are usually rare. For instance, surveys in Brazilian cities showed $4.7 \%$ (out of $43 \mathrm{M}$. musculus and $R$. rattus), 5\% (out of $181 R$. rattus) and $0.46 \%$ (out of $217 R$. rattus, $R$. norvegicus and M. musculus) of Toxoplasma rodent careers in the cities of Umuarama, Londrina and São Paulo, respectively (Ruffolo 2008, Araujo et al. 2010, Muradian et al. 2012) (see also Supplementary data for a review about data for rodents in the tropics).

As for other studies, the seroprevalence results may be discussed according to the sensitivity and specificity of the serological test. Seroprevalence in our study was evaluated through a modified-agglutination test which is the most commonly used for defining a possible infection in diverse species of animals, as there is no need for specific secondary antibodies. The cut-off is variable according to species and to studies (1:5-1:25) (Dubey \& Frenkel 1998, Dubey 2010). The most commonly considered cut-off is $1: 25$, but $T$. gondii has sometimes been isolated from animals with antibody titres below 1:25. That explains why we choose the cut-off of 1:16 that represents the lowest dilution available after elution of dried blood spot. The gold-standard for detection of $T$. in infected animals and hence to define the true prevalence is a mouse bioassay. This was not possible in the context of Niger. PCR-based method for Toxoplasma DNA detection on tissue samples (brain, muscles) is known to have a lower sensitivity than bioassay and serology (Hill et al. 2006, Truppel et al. 2010).

When considered separately, seroprevalences in Niamey show quite significant variations depending on the species, with low ( $<2 \%$ in Mastomys, Mus and Rattus) to moderate ( $>9 \%$ in Arvicanthis) values. This once again fits to what was observed for rodents elsewhere in the World, with species-specific seroprevalence ranging from close to null (e.g., 0.035\% of 571 house mice in Panama) (Frenkel et al. 1995) to $100 \%$ (e.g., 104 T. swinderi- anus in Nigeria) (Arene 1986) (Supplementary data). It is also noteworthy that the same rodent species can display extremely different seroprevalence depending on localities or countries. For instance, seroprevalence in $R$. rattus from Niamey is $1.6 \%$ while it reaches 3\% (out of 238 black rats) in Micronesia (Wallace 1973a, b), up to $50 \%$ (out of 74) in the Philippines (Salibay \& Claveria 2005).

These specific as well as geographic variations point toward a complex $T$. gondii epidemiology that most probably involves several interacting biotic and environmental factors (such as hosts communities structure, individual immunologic characteristics, climatic variables, water, landscape physiognomy and composition, as well as their respective spatio-temporal dynamics), thus making each situation potentially different from one another, even locally (Afonso et al. 2006).

Seropositive rodents were recorded across the year (Table III), encompassing all of the Sahelian seasons [from the warm and dry season (March and April), through the rainy season (June), to the cool and dry season (October and November)], thus suggesting that Toxoplasma infection may occur throughout the year in Niamey's rodents. However, diachronic monitoring within the same site was not feasible, thus precluding any conclusion about potential seasonal seroprevalence peaks.

Another question about the Toxoplasma sylvatic cycle is vertical transmission from a female rodent to its litter (Owen \& Trees 1998, Marshall et al. 2004, Hide et al. 2009). Although our data are limited both in nature (we score antibodies, not proper infection cases) and sample size, we can rely on three instances of multiple hence simultaneous captures to partly address this point (Table III). Indeed, when an adult female is caught with one or several juveniles, one can confidently consider that they are mother and descents; in the same manner, co-captured juveniles have good chances to belong to the same litter (Granjon \& Cosson 2008) (and references therein).

First, two seropositive juveniles of multimammate rats were captured together (NIA 243 and NIA 243b) (Table III). Unfortunately, no data about any adult is available here, thus making it impossible to decipher between independent environmental infections - for example at the same place, such as the nest - and vertical transmission. Second, an adult seropositive female of the black rat (NIA-CGA15a) (Table III) was caught with a seronegative juvenile. Third, a triple capture included a seronegative adult female and two seropositive juveniles of $A$. niloticus (NIALMO-20 and NIA-LMO-21) (Table III). These two latter cases bring poor support (though not refute) to vertical transmission and rather suggest that animals get infected from the environment (soil and water).

Interestingly, the more typical commensal species found in Niamey (M. natalensis, M. musculus and R. rattus) all display low seroprevalences. In particular, only six individuals of the native and widespread species in Niamey, i.e. M. natalensis, were found with detectable Toxoplasma antibodies in spite of a large sample size (n $=501$ ). This species is found within houses in all investigated parts of the city. Importantly, in these urban districts, cats may be numerous since a recent survey in 170 habitations in Niamey revealed that 119 of them $(70 \%)$ 
may be associated with the presence of domestic or stray cats (Garba 2012). These cats mainly survive from garbage and wild preys, something that may maximize the risk for them to get infected by ingestion of infected rodents. Low seroprevalence in Mastomys (which is, from far, the dominating species in most habitations, hence the most susceptible to be a major cats' prey) may limit cat predation-mediated infections through commensal rodents, hence in turn decreasing potential transmissions from cats to humans. Another important aspect for public health is the similarly low seroprevalences observed in M. musculus and $R$. rattus. Indeed, these two invasive species recently established in Niamey (Garba 2012) and it is possible that their populations may potentially extend within the city, potentially partly replacing the native $M$. natalensis (as this was observed for instance in some parts of Senegal) (Duplantier et al. 1991).

Bovine and ovine meat is traditionally well cooked in Niger. Moreover, no seropositive rodent could be found in our large sample ( $\mathrm{n}=59$ black rats) from the slaughter house (ABA) (Supplementary data). In addition, rodent meat consumption by humans is rather rare in Niger, especially in Niamey and most exclusively concerns young boys that occasionally hunt in gardens. Also, previous studies conducted in Nigeria (Olusi et al. 1994) suggest that rodent meat consumption, even not or poorly cooked, may not play a major role in human contamination. For all these reasons, following previous authors (Develoux et al. 1988, Julvez et al. 1996), we believe that contamination through meat consumption is most probably anecdotal in Niamey.

Low levels of $T$. gondii prevalence in both human (see above) and rodents (this study) are congruent with Sahelian climatic conditions such as very low hygrometry, soil and air temperatures as well as high ultraviolet irradiations levels which are poorly suitable for oocysts survival and sporulation [Dumas et al. (1991) reviewed in Tenter et al. (2000)]. This most probably also limits the chance of environmental contaminations. Nevertheless, such extreme and unfavourable conditions may be locally counteracted by human-mediated modifications of the habitat. In particular, the possibly major role of direct waterborne contamination has been receiving increasing support [e.g., reviewed in Jones \& Dubey (2010)]. In the absence of other feasible explanations, water was even speculated as a major source of toxoplasmic infection in pregnant women and children from Northern Niger (Dumas et al. 1991). Interestingly, we found here significantly higher seroprevalence in A. niloticus $(9.1 \%)$ which, in Niamey, is only found within irrigated gardens (Garba 2012). It was found in six out of the seven gardens that were investigated in the present survey (Supplementary data) and seropositive Nile grass rats were found in three of them (JCYA, J-DAR and J-LMO) (Figure, Supplementary data). Unfortunately, we were not able to statistically address this particular issue here, since we could not decipher between Arvicanthis-specific epidemiological properties and environmental (i.e. garden-associated) conditions. If rodent-borne toxoplasmosis was to be more frequent in such habitats/species, as strongly suggested by our data, Toxoplasma human prevalence in Niamey may increase during the coming years, following current extension of irrigated and cultivated surfaces all along the Niger River as well as the Gountou Yena wadi which both cross the city (Djima et al. 2010). Indeed, food habits are clearly switching towards higher consumption of vegetables (e.g., salads, cabbages) that are produced in urban gardens and sold directly in the different markets of town. Sources of watering are the river itself and/or wells where water temperatures should be consistent with oocyst survival (Jones \& Dubey 2010). Rodents such as Nile grass rats feed mainly on the cultivated vegetables (Dobigny et al. 2002) (our own observations and many farmers' personal communications). It was previously shown that risk of infection in French cats was higher with warm and moist weather (Afonso et al. 2006). In Niamey, temperatures are always high (the coldest month January is characterised by a normal minimal temperature of $16.6^{\circ} \mathrm{C}$ for the 19712000 period) (CRA meteorological database) and regular human-mediated irrigation may locally compensate the Sahelian aridity, thus favouring Toxoplasma infection of rodents inhabiting gardens. As such, the connection in Sahelian cities between oocysts, watered vegetables and rodents could be a key element of Toxoplasma circulation that may deserve to be further scrutinised.

To our knowledge, the present study is the first one to focus on $T$. gondii epidemiology in a Sahelian community of rodents. In spite of a large sample size, seroprevalence was found to be rather low, with a possible exception in A. niloticus that may sign species-specificity and/ or a predominant role of water-mediated infection in irrigated gardens. For a clearer view of the whole picture, several aspects need to be investigated. First, a proper study of true infection cases deserves to be conducted to confirm the absence of vertical transmission. Second, other epidemiological agents, such as water, cats, cattle and, of course, human are important to include. Finally, genomic data about of $T$. gondii that circulate in Africa are very rare (Mercier et al. 2010) and no data exist for Niger. Relevant analyses are thus urgently required to fill this gap since infectivity and morbidity of toxoplasmosis have been related to the protozoan genotype (Ajzenberg et al. 2002, 2009, Boothroyd \& Grigg 2002).

\section{ACKNOWLEDGEMENTS}

To D Mazier and the technical team of the ParasitologyMycology Department (INSERM/UPMC UMR S 945) from the Centre Hospitalier Universitaire Pitié-Salpêtrière (Paris, France), for facilitating our work by welcoming A Mercier in their laboratory, to Isabelle Villena and Dominique Aubert (University of Reims, National Center for Toxoplasma, France), for providing antigen for serological detection.

\section{REFERENCES}

Adamou A 2012. Mobilité résidentielle et processus d'étalement de la ville de Niamey, Niger, $\mathrm{PhD}$ Thesis, Université Abdou Moumouni, Niamey, 301 pp.

Afonso E, Thulliez P, Gilot-Fromont E 2006. Transmission of Toxoplasma gondii in an urban population of domestic cats (Felis catus). Int J Parasitol 36: 1373-1382.

Ajzenberg D, Cogne N, Paris L, Bessieres MH, Thulliez P, Filisetti D, Pelloux H, Marty P, Dardé ML 2002. Genotype of 86 Toxoplasma 
gondii isolates associated with human congenital toxoplasmosis and correlation with clinical findings. J Infect Dis 186: 684-689.

Ajzenberg D, Yera H, Marty P, Paris L, Dalle F, Menotti J, Aubert D, Franck J, Bessieres MH, Quinio D, Pelloux H, Delhaes L, Desbois N, Thulliez P, Robert-Gangneux F, Kauffmann-Lacroix C, Pujol S, Rabodonirina M, Bougnoux ME, Cuisenier B, Duhamel C, Duong TH, Filisetti D, Flori P, Gay-Andrieu F, Pratlong F, Nevez G, Totet A, Carme B, Bonnabau H, Dardé ML, Villena I 2009. Genotype of 88 Toxoplasma gondii isolates associated with toxoplasmosis in immunocompromised patients and correlation with clinical findings. J Infect Dis 199: 1155-1167.

Araujo JB, da Silva AV, Rosa RC, Mattei RJ, da Silva RC, RichiniPereira VB, Langoni H 2010. Isolation and multilocus genotyping of Toxoplasma gondii in seronegative rodents in Brazil. Vet Parasitol 174: 328-331.

Arene FO 1986. Prevalence of Toxoplasma gondii among West African rodent, Thryonomys swinderianus from the Niger Delta. J Hyg Epidemiol Microbiol Immunol 30: 215-217.

Boothroyd JC, Grigg ME 2002. Population biology of Toxoplasma gondii and its relevance to human infection: do different strains cause different disease? Curr Opin Microbiol 5: 438-442.

Burridge MJ, Bigler WJ, Forrester DJ, Hennemann JM 1979. Serologic survey for Toxoplasma gondii in wild animals in Florida. J Am Vet Med Assoc 175: 964-967.

Canon-Franco WA, Yai LE, Joppert AM, Souza CE, D’Auria SR, Dubey JP, Gennari SM 2003. Seroprevalence of Toxoplasma gondii antibodies in the rodent capybara (Hidrochoeris hidrochoeris) from Brazil. J Parasitol 89: 850.

Carme B, Aznar C, Motard A, Demar M, de Thoisy B 2002. Serologic survey of Toxoplasma gondii in noncarnivorous free-ranging neotropical mammals in French Guiana. Vector Borne Zoonotic Dis 2: 11-17.

Chinchilla M 1978. Epidemiology of toxoplasmosis in Costa Rica: the importance of domestic rodents. Rev Biol Trop 26 (Suppl. 1): 113-124.

de Roever-Bonnet H 1972. Toxoplasmosis in tropical Africa. Trop Geogr Med 24: 7-13.

de Thoisy B, Demar M, Aznar C, Carme B 2003. Ecologic correlates of Toxoplasma gondii exposure in free-ranging neotropical mammals. J Wildl Dis 39: 456-459.

Delacroix Y, Laporte P 1989. Prevalence of toxoplasmosis in a Sahelian zone. Med Trop 49: 161-162.

Desmonts G, Remington JS 1980. Direct agglutination test for diagnosis of Toxoplasma infection: method for increasing sensitivity and specificity. J Clin Microbiol 11: 562-568.

Develoux M, Candolfi E, Hanga-Doumbo S, Kien T 1988. Toxoplasmosis in Niger. A serological analysis of 400 subjects. Bull Soc Pathol Exot Filiales 81: 253-259.

Develoux M, Chandenier J, Tinni A 1989. Toxoplasmosis in pregnant women in Niamey (Niger). Bull Soc Pathol Exot Filiales 82: 406-409.

Djima ITH, N'Diaye M, Ali M, Saadou M 2010. Les algues des zones humides de Niamey: le genre Micrasterias Agardh ex Rahlfs (Desmidiaceae), In Annales de l'Université Abdou Moumouni, Niamey, A-XI, p. 134-141.

Dobigny G, Lecompte E, Tatard C, Gauthier P, Bâ K, Denys C, Duplantier JM, Granjon L 2008. An update on the taxonomy and geographic distribution of the cryptic species Mastomys kollmannspergeri (Muridae, Murinae) using combined cytogenetic and molecular data. $J$ Zool 276: 368-374.
Dobigny G, Nomao A, Gautun JC 2002. A cytotaxonomic survey of rodents from Niger: implications for systematics, biodiversity and biogeography. Mammalia 66: 495-523.

Dobigny G, Tatard C, Kane M, Gauthier P, Brouat C, Ba K, Duplantier JM 2011. A cytotaxonomic and DNA-based survey of rodents from Northern Cameroon and Western Chad. Mamm Biol 76: 417-427.

Dubey JP 2010. Toxoplasmosis of animals and humans, 2nd ed., CRC Press, Boca Raton, 313 pp.

Dubey JP, Bhaiyat MI, Macpherson CN, de Allie C, Chikweto A, Kwok OC, Sharma RN 2006. Prevalence of Toxoplasma gondii in rats (Rattus norvegicus) in Grenada, West Indies. J Parasitol 92: 1107-1108.

Dubey JP, Frenkel JK 1998. Toxoplasmosis of rats: a review, with considerations of their value as an animal model and their possible role in epidemiology. Vet Parasitol 77: 1-32.

Dubey JP, Velmurugan GV, Alvarado-Esquivel C, Alvarado-Esquivel D, Rodriguez-Pena S, Martinez-Garcia S, Gonzalez-Herrera A, Ferreira LR, Kwok OC, Su C 2009. Isolation of Toxoplasma gondii from animals in Durango, Mexico. J Parasitol 95: 319-322.

Dumas N, Cazaux M, Rivaillier P, Seguela JP 1985. Toxoplasmosis in the African tropical zone. Preliminary studies. Bull Soc Pathol Exot Filiales 78: 795-800.

Dumas N, Cazaux M, Seguela JP, Charlet JP 1991. Epidémiologie de la toxoplasmose chez la mère et l'enfant en Afrique tropicale. Bull Soc Pathol Exot Filiales 84: 645-658.

Duplantier JM, Granjon L, Adam F, Bâ K 1991. Répartition actuelle du rat noir (Rattus rattus) au Sénégal: facteurs historiques et écologies. In M Le Berre, L Le Guelte, Le rongeur et l'espace, Editions Raymond Chabaud, Paris, p. 339-346.

El Nahal HS, Morsy TA, Bassili WR, El Missiry AG, Saleh MS 1982. Antibodies against three parasites of medical importance in Rattus sp. collected in Giza Governorate, Egypt. J Egypt Soc Parasitol 12: 87-293.

Frenkel JK, Hassanein KM, Hassanein RS, Brown E, Thulliez P, Quintero-Nunez R 1995. Transmission of Toxoplasma gondii in Panama City, Panama: a five-year prospective cohort study of children, cats, rodents, birds, and soil. Am J Trop Med Hyg 53: 458-468.

Garba M 2012. Rongeurs urbains et invasion biologique au Niger: écologie des communautés et génétique des populations, $\mathrm{PhD}$ Thesis, Université Abdou Moumouni de Niamey, Niamey, 260 pp.

Granjon L, Cosson JF 2008. Social relationships in Mastomys huberti as deduced from field and genetic analyses of multiple capture data. Mammalia 72: 161-168.

Granjon L, Duplantier JM 2009. Les rongeurs d'Afrique Sahélo-Soudanienne, IRD Editions \& Publications Scientifiques du MNHN, Marseille, 216 pp.

Halos L, de Broucker CA, Perret C, Thomas M, Marié JL, Bretagne S, Boireau P, Davoust B 2007. Prevalence on Toxoplasma gondii in wild game meat from French Guyana, 21st International Conference of the World Association for the Advancement of Veterinary Parasitology, 2007 August 19-23, Gent, p. 474.

Hide G, Morley EK, Hughes JM, Gerwash O, Elmahaishi MS, Elmahaishi KH, Thomasson D, Wright EA, Williams RH, Murphy RG, Smith JE 2009. Evidence for high levels of vertical transmission in Toxoplasma gondii. Parasitology 136: 1877-1885.

Hill DE, Chirukandoth S, Dubey JP, Lunney JK, Gamble HR 2006. Comparison of detection methods for Toxoplasma gondii in naturally and experimentally infected swine. Vet Parasitol 141: 9-17.

Jittapalapong S, Sarataphan N, Maruyama S, Hugot JP, Morand S, Herbreteau V 2011. Toxoplasmosis in rodents: ecological survey and first evidences in Thailand. Vector Borne Zoonotic Dis 11: 231-237. 
Jones JL, Dubey JP 2010. Waterborne toxoplasmosis - recent developments. Exp Parasitol 124: 10-25.

Julvez J, Magnaval JF, Meynard D, Perie C, Baixench MT 1996. Seroepidemiology of toxoplasmosis in Niamey, Niger. Med Trop (Madr) 56: 48-50.

Lebel T, Ali A 2009. Recent trends in the Central and Western Sahel rainfall regime (1990-2007). J Hydrol 375: 52-64.

Lecompte E, Brouat C, Duplantier JM, Galan M, Granjon L, Loiseau A, Mouline K, Cosson JF 2005. Molecular identification of four cryptic species of Mastomys (Rodentia, Murinae). Biochem Syst Ecol 33: 681-689.

Lelong B, Rahelimino B, Candolfi E, Ravelojaona BJ, Villard O, Rasamindrakotroka AJ, Kien T 1995. Prevalence of toxoplasmosis in a population of pregnant women in Antananarivo (Madagascar). Bull Soc Pathol Exot 88: 46-49.

Lin S, Ling ZC, Zeng BC, Yang HY 1990. Prevalence of Toxoplasma gondii infection in man and animals in Guangdong, Peoples Republic of China. Vet Parasitol 34: 357-360.

Marshall PA, Hughes JM, Williams RH, Smith JE, Murphy RG, Hide G 2004. Detection of high levels of congenital transmission of Toxoplasma gondii in natural urban populations of Mus domesticus. Parasitology 128: 39-42.

Mercier A 2010. Approche écologique, épidémiologique et génétique de la biodiversité de Toxoplasma gondii en zone tropicale humide: exemples du Gabon et de la Guyane Française, PhD Thesis, Université de Limoges, Limoges, 289 pp.

Mercier A, Devillard S, Ngoubangoye B, Bonnabau H, Banuls AL, Durand P, Salle B, Ajzenberg D, Dardé ML 2010. Additional haplogroups of Toxoplasma gondii out of Africa: population structure and mouse-virulence of strains from Gabon. PLoS Negl Trop Dis 4: e876.

Mir NA, Chabra MB, Bhardwaj RM, Gautam OP 1982. Toxoplasma infection and some other protozoan parasites of the wild rat in India. Indian Vet J 59: 60-63.

Muradian V, Ferreira LR, Lopes EG, Esmerini PO, Pena HF, Soares RM, Gennari SM 2012. A survey of Neospora caninum and Toxoplasma gondii infection in urban rodents from Brazil. J Parasitol 98: 128-134

Murphy RG, Williams RH, Hughes JM, Hide G, Ford NJ, Oldbury DJ 2008. The urban house mouse (Mus domesticus) as a reservoir of infection for the human parasite Toxoplasma gondii: an unrecognised public health issue? Int J Environ Health Res 18: 177-185.

Olusi TA, Ajaya JA, Makinde AA 1994. Antibodies to Toxoplasma gondii in a rat-eating population on Benue State, Nigeria. Ann Trop Med Parasitol 88: 217-218.

Owen MR, Trees AJ 1998. Vertical transmission of Toxoplasma gondii from chronically infected house (Mus musculus) and field (Apodemus sylvaticus) mice determined by polymerase chain reaction. Parasitology 116: 299-304.
R Development Core Team 2009. R: a language and environment for statistical computing, R Foundation for Statistical Computing, Vienna, 409 pp.

Rifaat MA, Mahdi AH, Arafa MS, Nasr NT, Sadek MS 1971. Isolation of Toxoplasma from Rattus norvegicus in Egypt. Trans R Soc Trop Med Hyg 65: 788-789.

Rifaat MA, Nasr NT, Sadek MS, Arafa MS, Mahdi AH 1973. The role of the domestic rat, Rattus alexandrinus as a reservoir host of Toxoplasma gondii in Egypt. J Trop Med Hyg 76: 257-258.

Robert-Gangneux F, Dardé ML 2012. Epidemiology of and diagnostic strategies for toxoplasmosis. Clin Microbiol Rev 25: 264-296.

Ruffolo BB 2008. Toxoplasma gondii e enteroparasitoses em ratos urbanos capturados em locais de reciclagem de resíduos sólidos na cidade de Londrina, MsC Thesis, Londrina State University, Londrina, $60 \mathrm{pp}$

Ruiz A, Frenkel JK 1980. Intermediate and transport hosts of Toxoplasma gondii in Costa Rica. Am J Trop Med Hyg 29: 1161-1166.

Salibay CC, Claveria FG 2005. Serologic detection of Toxoplasma gondii infection in Rattus spp collected from three different sites in Dasmarinas, Cavite, Philippines. Southeast Asian J Trop Med Public Health 36 (Suppl. 4): 46-49.

Sidikou HA 2011. Notes sur l'histoire de Niamey. In M Ascani, Niamey à 360 : capitale de la République du Niger, M Ascani, Niamey, p. 3-14.

SNIS - National Service for Sanitary Information 2010. Rapport annuel 2010 du Système National d'Information Sanitaire. Available from: snis.cermes.net/donnees.php.

Tenter AM, Heckeroth AR, Weiss LM 2000. Toxoplasma gondii: from animals to humans. Int J Parasitol 30: 1217-1258.

Truppel JH, Reifur L, Montiani-Ferreira F, Lange RR, Vilani RGC, Gennari SM, Thomaz-Soccol V 2010. Toxoplasma gondii in Capybara (Hydrochaeris hydrochaeris) antibodies and DNA detected by IFAT and PCR. Parasitol Res 107: 141-146.

Wallace GD 1973a. Intermediate and transport hosts in the natural history of Toxoplasma gondii. Am J Trop Med Hyg 22: 456-464.

Wallace GD 1973b. The role of the cat in the natural history of Toxoplasma gondii. Am J Trop Med Hyg 22: 313-322.

Wilson DE, Reeder DAM 2005. Mammal species of the World: a taxonomic and geographic reference, 2nd ed., Johns Hopkins Univ Press, Baltimore, 1207 pp.

Yai LE, Ragozo AM, Aguiar DM, Damaceno JT, Oliveira LN, Dubey JP, Gennari SM 2008. Isolation of Toxoplasma gondii from capybaras (Hydrochaeris hydrochaeris) from São Paulo state, Brazil. J Parasitol 94: 1060-1063.

Yin CC, He Y, Zhou DH, Yan C, He XH, Wu SM, Zhou Y, Yuan ZG, Lin RQ, Zhu XQ 2010. Seroprevalence of Toxoplasma gondii in rats in southern China. J Parasitol 96: 1233-1234. 
Recapitulation of studies dealing with Toxoplasma seroprevalence in rodents within intertropical regions

\begin{tabular}{|c|c|c|c|}
\hline Species & Region & $\begin{array}{l}\text { Seroprevalence } \\
\quad \%(\mathrm{n} / \mathrm{n})\end{array}$ & References \\
\hline Rodents (not specified) & China & $0.9(9 / 955)$ & Lin et al. (1990) \\
\hline Wild rodents & Gabon & $2.7(1 / 37)$ & Mercier (2010) \\
\hline Bandicota indica & Thailand & $2.7(1 / 37)$ & Jittapalapong et al. (2011) \\
\hline Bandicota savilei & Thailand & $0(0 / 11)$ & Jittapalapong et al. (2011) \\
\hline Cuniculus paca & $\begin{array}{l}\text { French Guiana } \\
\text { French Guiana }\end{array}$ & $\begin{array}{c}60.9(14 / 23) \\
60(22 / 37)\end{array}$ & $\begin{array}{c}\text { Carme et al. (2002) } \\
\text { de Thoisy et al. (2003) }\end{array}$ \\
\hline Dasyprocta leporina & $\begin{array}{l}\text { French Guiana } \\
\text { French Guiana }\end{array}$ & $\begin{array}{c}23.3(10 / 43) \\
18(8 / 45)\end{array}$ & $\begin{array}{c}\text { Carme et al. (2002) } \\
\text { de Thoisy et al. (2003) }\end{array}$ \\
\hline Hydrochoerus hydrochaeris & $\begin{array}{c}\text { Brazil } \\
\text { Brazil } \\
\text { Brazil } \\
\text { French Guiana }\end{array}$ & $\begin{array}{c}69.8(104 / 149) \\
75(49 / 64) \\
61.5(16 / 26) \\
6.7(2 / 30)\end{array}$ & $\begin{array}{c}\text { Canon-Franco et al. (2003) } \\
\text { Yai et al. (2008) } \\
\text { Truppel et al. (2010) } \\
\text { Halos et al. (2007) }\end{array}$ \\
\hline Leopoldamys sabanus & Thailand & $12.5(2 / 16)$ & Jittapalapong et al. (2011) \\
\hline Maxomys surifer & Thailand & $5.3(2 / 38)$ & Jittapalapong et al. (2011) \\
\hline Menetes berdmorei & Thailand & $7.7(4 / 52)$ & Jittapalapong et al. (2011) \\
\hline Mus musculus & $\begin{array}{l}\text { Brazil } \\
\text { Costa Rica } \\
\text { Mexico } \\
\text { Panama }\end{array}$ & $\begin{array}{c}0(0 / 19) \\
5(5 / 100) \\
3.1(4 / 127) \\
0.035(2 / 571)\end{array}$ & $\begin{array}{c}\text { Araujo et al. (2010) } \\
\text { Chinchilla (1978) } \\
\text { Dubey et al. (2009) } \\
\text { Frenkel et al. (1995) }\end{array}$ \\
\hline Myoprocta acouchy & French Guiana & $4(1 / 26)$ & de Thoisy et al. (2003) \\
\hline Niviventer fulvescens & Thailand & $0(0 / 13)$ & Jittapalapong et al. (2011) \\
\hline Rattus spp & $\begin{array}{l}\text { Costa Rica } \\
\text { Mexico }\end{array}$ & $\begin{array}{c}30(7 / 23) \\
0.8(2 / 249)\end{array}$ & $\begin{array}{l}\text { Chinchilla (1978) } \\
\text { Dubey et al. (2009 }\end{array}$ \\
\hline Rattus exulans & $\begin{array}{l}\text { Hawaii } \\
\text { Thailand }\end{array}$ & $\begin{array}{c}7(5 / 85) \\
1.3(1 / 79)\end{array}$ & $\begin{array}{l}\text { Wallace (1973a, b) } \\
\text { Jittapalapong et al. (2011) }\end{array}$ \\
\hline Rattus tanezumi & $\begin{array}{l}\text { China } \\
\text { Thailand }\end{array}$ & $\begin{array}{c}3(3 / 101) \\
7.1(11 / 156)\end{array}$ & $\begin{array}{c}\text { Yin et al. (2010) } \\
\text { Jittapalapong et al. (2011) }\end{array}$ \\
\hline Rattus norvegicus & $\begin{array}{c}\text { China } \\
\text { Costa Rica } \\
\text { Egypt } \\
\text { Egypt } \\
\text { United States of America } \\
\text { Grenada Island } \\
\text { Hawaii } \\
\text { India } \\
\text { Panama } \\
\text { Philippines } \\
\text { Thailand }\end{array}$ & $\begin{array}{c}3.4(4 / 116) \\
11.2(12 / 107) \\
26.7(16 / 60) \\
34(34 / 100) \\
12(2 / 8) \\
0.8(2 / 238) \\
1.4(1 / 73) \\
0(0 / 186) \\
23.3(52 / 226) \\
60(50 / 83) \\
0(0 / 34)\end{array}$ & $\begin{array}{c}\text { Yin et al. (2010) } \\
\text { Ruiz \& Frenkel (1980) } \\
\text { El Nahal et al. (1982) } \\
\text { Rifaat et al. (1971) } \\
\text { Burridge et al. (1979) } \\
\text { Dubey et al. (2006) } \\
\text { Wallace (1973a, b) } \\
\text { Mir et al. (1982) } \\
\text { Frenkel et al. (1995) } \\
\text { Salibay \& Claveria (2005) } \\
\text { Jittapalapong et al. (2011) }\end{array}$ \\
\hline Rattus rattus & $\begin{array}{l}\text { Africa } \\
\text { Brazil } \\
\text { Egypt } \\
\text { Egypt } \\
\text { Florida } \\
\text { Gabon } \\
\text { Hawaï } \\
\text { Micronesia } \\
\text { Philippines }\end{array}$ & $\begin{array}{c}8.2(5 / 61) \\
0(0 / 24) \\
42.7(47 / 110) \\
16.7(2 / 12) \\
13.8(5 / 38) \\
2.3(1 / 43) \\
8(36 / 476) \\
3(7 / 238) \\
50(37 / 74)\end{array}$ & $\begin{array}{c}\text { de Roever-Bonnet (1972) } \\
\text { Araujo et al. (2010) } \\
\text { Rifaat et al. (1973) } \\
\text { El Nahal et al. (1982) } \\
\text { Burridge et al. (1979) } \\
\text { Mercier (2010) } \\
\text { Wallace (1973a, b) } \\
\text { Wallace (1973a, b) } \\
\text { Salibay \& Claveria (2005) }\end{array}$ \\
\hline Spermophilus variegatus & Mexico & $0(0 / 69)$ & Dubey et al. (2009) \\
\hline Thryonomys swinderianus & Nigeria & $100(104 / 104)$ & Arene (1986) \\
\hline
\end{tabular}

taxonomic nomenclature follows the last edition of the mammalian systematics reference book (Wilson \& Reeder 2005). 
Nomenclature, type and Global Positioning System (GPS) coordinates of all 46 trapping sites

\begin{tabular}{|c|c|c|c|c|c|c|c|}
\hline \multirow[b]{2}{*}{ Site } & \multirow[b]{2}{*}{ Description } & \multicolumn{2}{|c|}{ GPS } & \multicolumn{4}{|c|}{ Rodents } \\
\hline & & $\begin{array}{l}\text { Latitude } \\
\qquad(\mathrm{N})\end{array}$ & $\begin{array}{l}\text { Longitude } \\
\text { (E) }\end{array}$ & Species & (n) & Identification & $\begin{array}{c}\text { Seropositive } \\
\text { (n) }\end{array}$ \\
\hline NA & NA & \multicolumn{2}{|c|}{ NA } & Rattus rattus & 1 & $\mathrm{M}$ & 0 \\
\hline ABA & Slaughter house & 13.48950 & 2.12275 & R. rattus & 59 & $\mathrm{M}, \mathrm{G}$ & 0 \\
\hline BAF2 & Habitations & 13.54401 & 2.13570 & Mastomys natalensis & 32 & PCR-RFLP (18) & 0 \\
\hline BAN & Habitations & 13.52161 & 2.11670 & R. rattus & 1 & $\mathrm{M}$ & 0 \\
\hline BOU & Habitations & 13.53742 & 2.11331 & M. natalensis & 46 & PCR-RFLP (30), K (4) & 0 \\
\hline CGA & Habitations & 13.50222 & 2.11235 & M. natalensis & 1 & PCR-RFLP (1) & 0 \\
\hline $\mathrm{COA}$ & Habitations & 13.53571 & 2.07399 & M. natalensis & 2 & PCR-RFLP (1) & 0 \\
\hline CRA-1 & Fallow lands & 13.49235 & 2.09877 & Cricetomys gambianus & 4 & $\mathrm{M}$ & 0 \\
\hline CRA-2 & Fallow lands & 13.49655 & 2.10079 & $\begin{array}{c}\text { C. gambianus } \\
\text { Taterillus gracilis }\end{array}$ & $\begin{array}{l}4 \\
2\end{array}$ & $\begin{array}{c}M \\
K(2)\end{array}$ & $\begin{array}{l}0 \\
0\end{array}$ \\
\hline CRA-3 & Fallow lands & 13.50060 & 2.10141 & Arvicanthis niloticus & 4 & $\mathrm{M}$ & 0 \\
\hline CYA & Habitations & 13.51204 & 2.09884 & $\begin{array}{c}\text { M. natalensis } \\
\text { R. rattus }\end{array}$ & $\begin{array}{c}49 \\
2\end{array}$ & $\begin{array}{c}\text { PCR-RFLP (26) } \\
\text { M, G }\end{array}$ & $\begin{array}{l}0 \\
0\end{array}$ \\
\hline DAR & Habitations & 13.54624 & 2.09594 & M. natalensis & 39 & PCR-RFLP (39), K (2) & 0 \\
\hline GAM & Habitations & 13.49392 & 2.12501 & M. natalensis & 18 & PCR-RFLP (10) & 0 \\
\hline GAM-1 & Habitations & 13.49792 & 2.12705 & M. natalensis & 2 & PCR-RFLP (1) & 0 \\
\hline GAW & Habitations & 13.48970 & 2.10232 & M. natalensis & 6 & PCR-RFLP (1) & 1 \\
\hline GNA & Habitations & 13.47908 & 2.11402 & M. natalensis & 23 & PCR-RFLP (16), K (2) & 1 \\
\hline GOU & Habitations & 13.51856 & 2.10883 & M. musculus & 1 & $\mathrm{M}$ & 0 \\
\hline GRM & Habitations & 13.51882 & 2.11500 & $\begin{array}{l}\text { M. musculus } \\
\text { R. rattus }\end{array}$ & $\begin{array}{c}60 \\
5\end{array}$ & $\begin{array}{l}\mathrm{M}, \mathrm{K}(5) \\
\mathrm{M}, \mathrm{G}\end{array}$ & $\begin{array}{l}1 \\
0\end{array}$ \\
\hline GRM-M & Market & 13.51527 & 2.11732 & R. rattus & 3 & $\mathrm{M}, \mathrm{G}$ & 0 \\
\hline J-CYA & $\begin{array}{c}\text { Industrial store house } \\
\text { Gardens }\end{array}$ & 13.52029 & 2.08104 & $\begin{array}{l}\text { R. rattus } \\
\text { A. niloticus }\end{array}$ & $\begin{array}{l}8 \\
1\end{array}$ & $\begin{array}{c}\mathrm{M}, \mathrm{G} \\
\mathrm{M}\end{array}$ & $\begin{array}{l}0 \\
1\end{array}$ \\
\hline J-DAR & Gardens & 13.54714 & 2.09238 & A. niloticus & 5 & M & 1 \\
\hline \multirow{2}{*}{ J-GAM } & Gardens & 13.48473 & 2.12775 & A. niloticus & 11 & M, K (2) & 0 \\
\hline & Houses within garden & & & M. natalensis & 1 & PCR-RFLP (1) & 0 \\
\hline \multirow[t]{2}{*}{ J-KIR1 } & Gardens & 13.49397 & 2.11170 & A. niloticus & 4 & $\mathrm{M}$ & 0 \\
\hline & Houses within garden & & & M. natalensis & 8 & PCR-RFLP (2) & 0 \\
\hline J-KIR2 & Gardens & 13.47573 & 2.09936 & C. gambianus & 2 & $\mathrm{M}$ & 0 \\
\hline \multirow[t]{2}{*}{ J-LMO } & Gardens & 13.50880 & 2.07810 & A. niloticus & 19 & M, K (2) & 4 \\
\hline & & & & C. gambianus & 2 & $\mathrm{M}$ & 0 \\
\hline J-NOG & Gardens & 13.50558 & 2.09723 & A. niloticus & 22 & $\mathrm{M}$ & 0 \\
\hline KAR & Habitations & 13.49366 & 2.09650 & M. natalensis & 42 & PCR-RFLP (6), K (2) & 1 \\
\hline KAR-1 & Habitations & 13.49143 & 2.08843 & M. natalensis & 11 & $\mathrm{~K}(5)$ & 1 \\
\hline KAR-2 & Habitations & 13.49316 & 2.09262 & M. natalensis & 9 & PCR-RFLP (1) & 0 \\
\hline KIR & Industrial complex & 13.49489 & 2.10978 & R. rattus & 16 & $\mathrm{M}, \mathrm{G}$ & 0 \\
\hline KIR-1 & Habitations & 13.48022 & 2.09984 & M. natalensis & 5 & PCR-RFLP (1) & 0 \\
\hline KOT & Habitations & 13.58922 & 2.10928 & M. natalensis & 10 & PCR-RFLP (8) & 0 \\
\hline KOU-1 & Habitations & 13.56106 & 2.04155 & M. natalensis & 3 & PCR-RFLP (1) & 0 \\
\hline LMO & Habitations & 13.50696 & 2.07653 & M. natalensis & 34 & PCR-RFLP (22), K (4) & 0 \\
\hline \multirow[t]{2}{*}{ PEM } & Market & 13.51396 & 2.10997 & M. natalensis & 9 & PCR-RFLP (3) & 2 \\
\hline & & & & R. rattus & 7 & $\mathrm{M}, \mathrm{G}$ & 0 \\
\hline PGP & Public building & 13.52093 & 2.09161 & R. rattus & 1 & $\mathrm{M}$ & 0 \\
\hline PKE & Habitations & 13.48536 & 2.10164 & M. natalensis & 40 & PCR-RFLP (23), K (2) & 0 \\
\hline REC & Habitations & 13.54157 & 2.08950 & M. natalensis & 1 & PCR-RFLP (1) & 0 \\
\hline ROF & Habitations & 13.52081 & 2.15193 & M. natalensis & 12 & PCR-RFLP (9), K (2) & 0 \\
\hline ROF-1 & Habitations & 13.52358 & 2.14766 & M. natalensis & 7 & PCR-RFLP (2) & 0 \\
\hline RTO & Store house & 13.49539 & 2.07916 & M. natalensis & 5 & PCR-RFLP (1) & 0 \\
\hline TCH & Habitations & 13.58936 & 2.10137 & M. natalensis & 16 & PCR-RFLP (16) & 0 \\
\hline WAD & Habitations & 13.51820 & 2.14351 & M. natalensis & 10 & PCR-RFLP (9), K (2) & 0 \\
\hline WAD-1 & Coach station & 13.51186 & 2.14032 & R. rattus & 1 & $\mathrm{M}$ & 0 \\
\hline YAB & Habitations & 13.52740 & 2.08175 & M. natalensis & 23 & PCR-RFLP (10), K (1) & 0 \\
\hline YAB-1 & Habitations & 13.52891 & 2.08186 & M. natalensis & 10 & PCR-RFLP (1) & 0 \\
\hline YAH & Habitations & 13.53435 & 2.08208 & M. natalensis & 28 & PCR-RFLP (17), K (4) & 0 \\
\hline
\end{tabular}

G: genotyping; K: karyotyping; M: morphology; NA: not available (individual from Niamey, but with no precise geographic origin); PCR-RFLP: polymerase chain reaction-restriction fragment length polymorphism. 